\title{
Thermal Performance Analysis of Reinforced Concrete Floor Structure with Radiant Floor Heating System in Apartment Housing
}

\author{
Young-Sun Jeong and Hae-Kwon Jung \\ Building \& Urban Research Institute, Korea Institute of Civil Engineering and Building Technology, 283 Goyangdae-Ro, \\ Ilsanseo-Gu, Goyang 411-712, Republic of Korea
}

Correspondence should be addressed to Young-Sun Jeong; sunj74@kict.re.kr

Received 20 March 2015; Revised 19 June 2015; Accepted 21 June 2015

Academic Editor: Robert Cerný

Copyright (C) 2015 Y.-S. Jeong and H.-K. Jung. This is an open access article distributed under the Creative Commons Attribution License, which permits unrestricted use, distribution, and reproduction in any medium, provided the original work is properly cited.

The use of the resilient materials in the radiant floor heating systems of reinforced concrete floor in apartment housing is closely related to the reduction of the floor impact sound and the heating energy loss. This study examined the thermal conductivity of expanded polystyrene (EPS) foam used for the resilient material in South Korea and analysed the thermal transfer of reinforced concrete floor structure according to the thermal conductivity of the resilient materials. 82 EPS specimens were used to measure the thermal conductivity. The measured apparent density of EPS resilient materials ranged between 9.5 and $63.0 \mathrm{~kg} / \mathrm{m}^{3}$, and the thermal conductivity ranged between 0.030 and $0.046 \mathrm{~W} /(\mathrm{m} \cdot \mathrm{K})$. As the density of resilient materials made of expanded polystyrene foam increases, the thermal conductivity tends to proportionately decrease. To set up reasonable thermal insulation requirements for radiant heating floor systems, the thermal properties of floor structure according to thermal insulation materials must be determined. Heat transfer simulations were performed to analyze the surface temperature, heat loss, and heat flow of floor structure with radiant heating system. As the thermal conductivity of EPS resilient material increased 1.6 times, the heat loss was of $3.4 \%$ increase.

\section{Introduction}

In Korea, apartment houses occupied the highest ratio at $86.4 \%$ of the residential buildings. Apartment houses account for more than $50 \%$ of all housing types, and since the $1990 \mathrm{~s}$ high-rise apartment buildings higher than 15 stories, sometimes 30 stories, have been constructed to efficiently utilize the relatively small land area $\left(99,373 \mathrm{~km}^{2}\right)$ of Korea having a high population density [1]. A number of households are living next door to each other separated only by a wall or floor. As a single reinforced concrete slab separates households in apartments, the floor impact sound and heat loss from above can be easily transferred to the household below and to the outside of the household. So there are many problems related to thermal performance and sound proofing. In particular, floor impact sound is irritating to residents and causes a great deal of complaints in residential buildings such as the apartments. The energy for space and water heating is the largest energy consumption in the residential buildings.

The reinforced concrete floor structure with radiant floor heating system (ONDOL) has been used conventionally for residential buildings in Korea [2,3]. This reinforced concrete (RC) floor structure consists of the reinforced concrete slab, the insulation layer with resilient materials, the radiant floor heating layer, the heat storage layer, and floor finishing materials. Hot water from a boiler is supplied to the plastic pipe in the radiant floor heating layer underneath the floor surface. The hot water circulates through the embedded plastic pipe heating the floor for heating space. Installing resilient materials between the concrete slab and the radiant floor heating layer in radiant floor heating system is known as the most popular method of reducing floor impact sound and heat loss in Korean apartment housings. In general, the thickness of resilient materials is $10-20 \mathrm{~mm}$. 
The use of resilient materials in floor heating systems is closely related to the reduction of the floor impact sound and heating energy loss. In Korea, the thermal insulation performance of building envelope simply involves the thickness of the insulation materials and the thermal transmission properties of the wall and floor systems by region $[4,5]$. The floor structure of apartment houses must have certain of floor impact sound performance (lightweight impact sound is $58 \mathrm{~dB}$ or less and heavyweight impact sound is $50 \mathrm{~dB}$ or less) and thermal resistance $\left(1.23 \mathrm{~m}^{2} \mathrm{~K} / \mathrm{W}\right)$. In a previous study, Kim et al. [1] published a study that holds that as the dynamic stiffness of resilient materials decreased, the floor impact sound level also decreased in floor heating system. There was a correlation between the dynamic stiffness and the heavyweight impact sound. Jeong et al. [6] have measured the thermal conductivity and density of the resilient materials and examined the correlation of these. But there has been no study that tried to analyze the heat transfer RC floor structure with radiant floor heating system as thermal property of resilient materials.

Several studies have been conducted on the effects of thermal transfer and analysis methods of such in a field of building energy engineering. Song [2] recommended that the floor finishing materials over the floor heating system in Korea should be chosen by the heat flux based on the heating load and should be thermophysiologically comfortable. Lee et al. [3] published a study that the thin flooring panel with enhanced thermal efficiency in radiant floor heating system provided $7.2 \%$ energy reduction compared to the conventional wooden flooring panels in apartment housing. Liu et al. [7] developed two-heat transfer model of the existing heat transfer process for in-slab heating floor. The study by Jin et al. [8] presents a method for calculating the floor surface temperature in radiant floor heating/cooling system based on the numerical model. Larbi [9] presents regression models of the thermal transmittance for three types of building walls (slab-on-grade floor-wall junction, floor-wall junction, and roof-wall junction) of $2 \mathrm{D}$ thermal brides. Theodosiou and Papadopoulos [10] recommended that the thermal bridges are not considered by the calculation procedure for the energy demand of buildings; actual thermal losses in the cases of such buildings are by up to $35 \%$ higher than the initially estimated ones. Song et al. [11] analysed the thermal transfer through thermal bridge of wall-slab joint on the annual heat loss of apartment houses with 3D transient heat transfer simulation modelling. Kaynakli [12] carried out investigation of the effect of various parameters on the optimum insulation thickness for external walls by considering cost and energy savings.

This study examines the thermal conductivity of resilient material used in RC floor structure with radiant floor heating systems in Korea and conducted a thermal transfer analysis of floor systems according to thermal conductivity of resilient materials in apartment housing.

\section{Materials and Methods}

2.1. Specimen Preparation. Resilient materials, currently used in Korea, are made of expanded polystyrene (EPS), expanded polypropylene (EPP), urethane ranges, ethylene-vinyl acetate copolymer (EVA), polyethylene (PE), glass wool (GW), mineral wool (MW), extruded polystyrene (XPS), extruded polyester fibers, and other composite materials $[1,5]$. Resilient material that was used for the measurements in this study was the expanded polystyrene (EPS) foam, which is widely used in South Korea as a building insulation material. Expanded polystyrene is thermoplastic that is manufactured by fusing small beads of the materials. It is usually white and is made of preexpanded polystyrene beads. It is a rigid and tough, closed-cell structure that is strong enough for use in many applications [13].

This study collected EPS resilient materials that were sold in the building materials market of South Korea from 2008 to 2010 . Among the 93 test samples collected in this study, 82 EPS resilient material foams were finally selected and were used to test the thermal conductivity. The test specimens, the dimensions of which were $300 \times 300 \mathrm{~mm}$ on a flat board, were prepared in this study, and their thickness was $20 \mathrm{~mm}$, $30 \mathrm{~mm}, 50 \mathrm{~mm}$, and $90 \mathrm{~mm}$. Three specimens were tested for each thickness. They were allowed to stabilize the hydrothermal condition at laboratory temperature $\left(20^{\circ} \mathrm{C}\right)$ for 3 days. All the test specimens were tested after 3 days in this study.

The microscope investigation was measured using a polarizing microscope instrument for taking surface condition photograph of the test specimen. We observed the surface condition and cell shape of the EPS resilient material foam. The microscope image of typical EPS foam is shown in Figure 1. As shown in this figure, the EPS resilient material has a smooth surface, uniform structure, and closed-cell structure. This closed-cell structure acts as a thermal insulator.

2.2. Experimental Test. The measurement methods applied to the test of the thermal conductivity in this study are KS L 9016 Method [14] for measuring thermal conductivity of insulator and ISO 8301 [15]. Measurements were taken with the heat flow meter method (HFM, Figure 2(a)). The mean temperature was $20 \pm 1^{\circ} \mathrm{C}$ for the measurement of the thermal conductivity. The measured result of thermal conductivity value was the average value of three specimens with the same thickness. The volume and weight of the specimens were measured with a digital micrometer (Figure 2(b)) with a $0.001 \mathrm{~mm}$ resolution, and the apparent density was measured with a digital scale (Figure 2(c)) with a $0.001 \mathrm{~g}$ resolution. Apparent density can be determined with the weight based on unit volume when test specimen includes the skins during production. During the experimental procedure, the test equipment and the test specimens are kept in the environmental conditions at $23 \pm 2^{\circ} \mathrm{C}$ and $50 \pm 5 \%$ of relative humidity.

2.3. Numerical Simulation. The configuration of the materials of floor structure was modelled based on the typical floor $[4,16]$ applicable to most of the houses in South Korea. The typical reinforced concrete floor structure for the house has four layers: the finishing layer, the heating layer, the insulation layer, and the structure layer. The heating layer has a thermal storage layer and a hot water pipe as plastic pipe. For this numerical simulation, the floor constructions were PVC flooring $(d=2 \mathrm{~mm})$, cement $\operatorname{mortar}(d=40 \mathrm{~mm})$, 


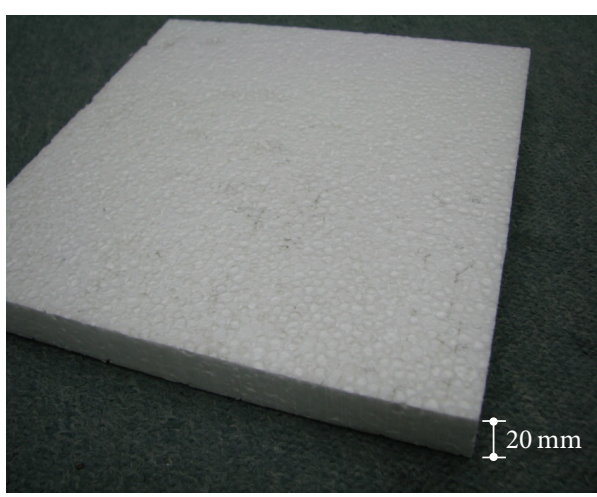

(a)

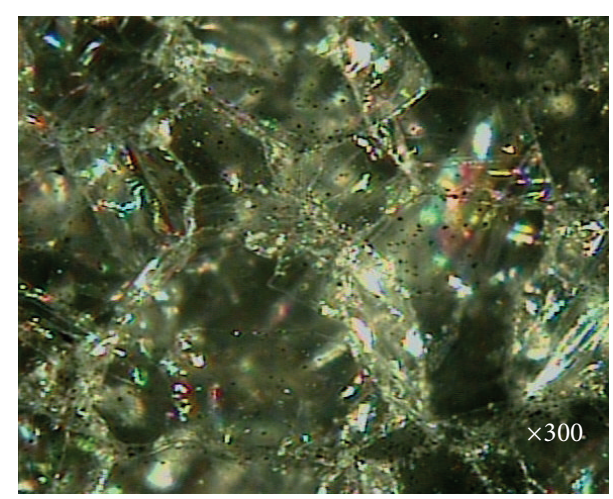

(b)

FIGURE 1: Expanded polystyrene (EPS) resilient material. (a) EPS specimen for testing thermal conductivity; (b) microscope image of 300 magnifications.

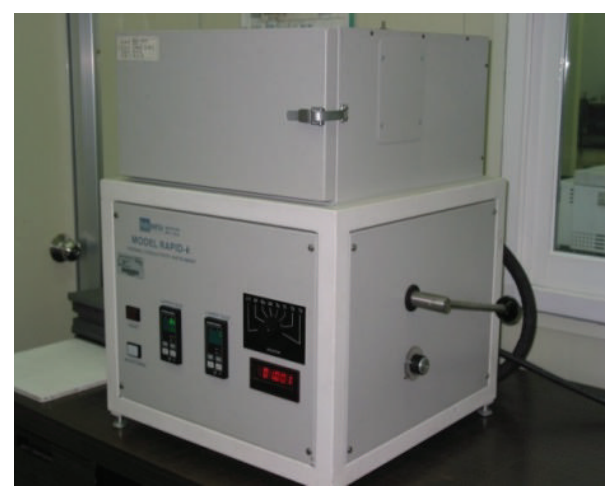

(a) Thermal conductivity instrument

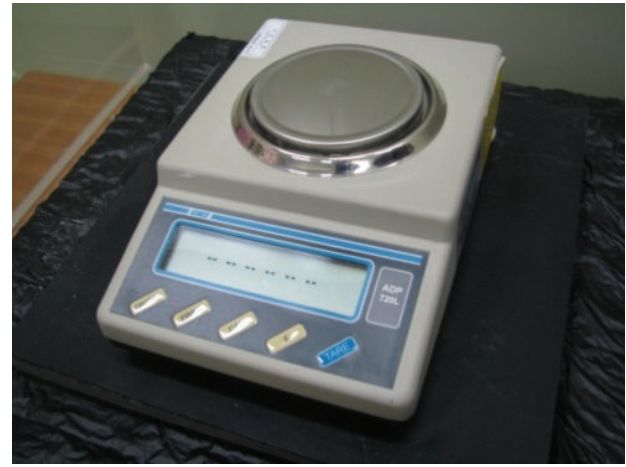

(c) Weight electronic balance

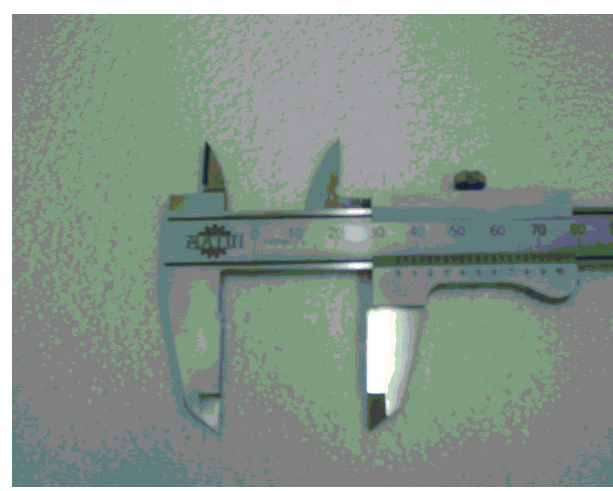

(b) Vernier calipers

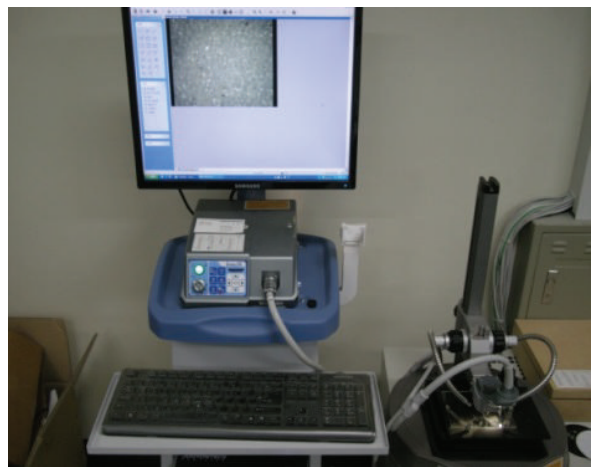

(d) Polarizing microscope

FIGURE 2: Test equipment.

hot water pipe, lightweight concrete $(d=40 \mathrm{~mm})$, resilient material ( $d=20 \mathrm{~mm}$ ), and $210 \mathrm{~mm}$ thick reinforced concrete slab. For the heating space, $15 \mathrm{~mm}$ diameter pipe was installed with a $230 \mathrm{~mm}$ narrow pitch in a $40 \mathrm{~mm}$ thick cement mortar. Geometric model and material configuration are provided in Figure 3. Table 1 shows the thermal characteristics of each construction material. As shown in Table 1, the value of the thermal conductivity of the resilient material was derived from the results of the experiment that was conducted in this study.
To analyze the thermal performance of floor systems, the Physibel software was used because it is capable of steady-state heat transfer analysis. The Physibel TRISCO program is meant for heat transfer simulation that focuses on building physics [17]. This program allows calculating three-dimensional (3D) steady-state heat transfer, based on the finite difference method in objects described in a rectangular grid. So it calculates the distribution of heat flow and temperature under steady state conditions via a grid meshing. This program allows simulations fully compliant 


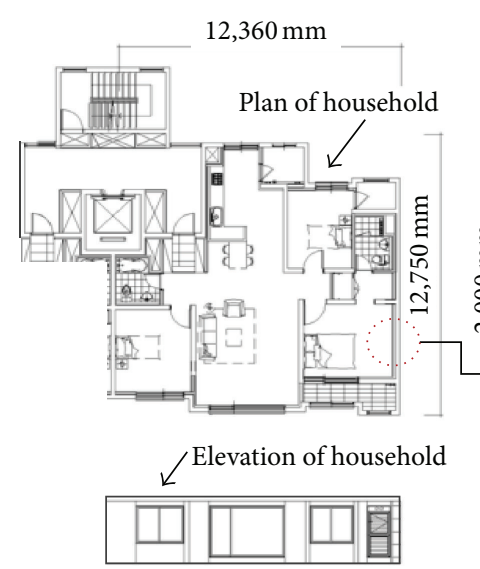

(a)

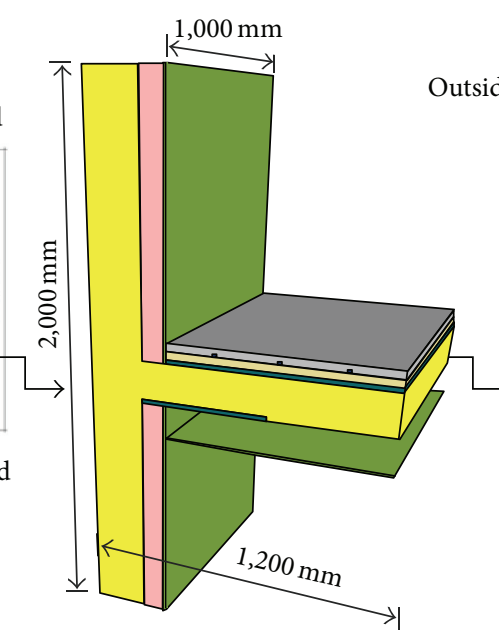

(b)

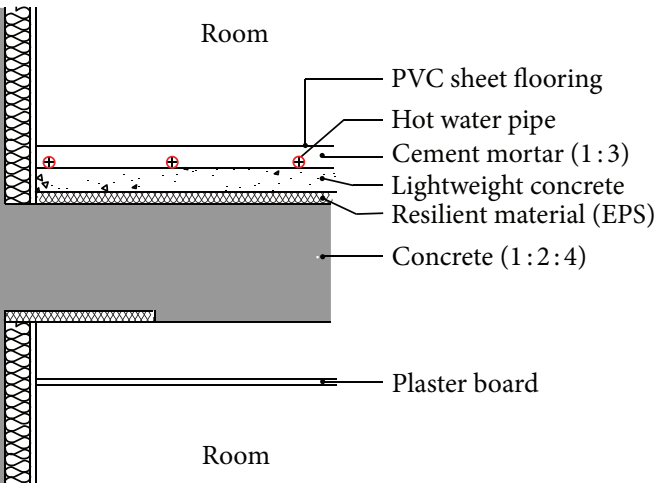

(c)

FIGURE 3: Thermal physical model of floor construction used in this study. (a) Plan of apartment housing; (b) modelling image (3D); (b) detailed construction structure.

TABLE 1: Material properties and the thermal characteristics of each material.

\begin{tabular}{lccc}
\hline Material & $\begin{array}{c}\text { Thickness } \\
(\mathrm{mm})\end{array}$ & $\begin{array}{c}\text { Density } \\
\left(\mathrm{kg} / \mathrm{m}^{3}\right)\end{array}$ & $\begin{array}{c}\text { Thermal conductivity } \\
(\mathrm{W} /(\mathrm{m} \cdot \mathrm{K}))\end{array}$ \\
\hline PVC sheet flooring & 2 & 1,500 & 0.19 \\
Cement mortar & 40 & 2,000 & 1.4 \\
Hot water pipe & 15 & 930 & 0.324 \\
Lightweight concrete & 40 & 650 & 0.16 \\
Resilient material & 20 & $9.5-63$ & - \\
Concrete & 210 & 2,240 & 1.6 \\
Plaster board & 9 & 940 & 0.18 \\
\hline
\end{tabular}

with the standard EN ISO 10211-1 [18]. Figure 3(b) shows the simulation model and Figure 3(c) shows vertical section of the external wall-RC floor joints and materials construction. Simulations were performed on the basis of a model with dimension $2.0 \mathrm{~m}$ (height) $\times 1.2 \mathrm{~m}$ (width) $\times 1.0 \mathrm{~m}$ (depth) which locates the middle storey of apartment housing in Korea. 3D transient heat transfer simulations were performed with a time step interval of 30 minutes. The calculation parameters for simulation are shown in Table 2.

Boundary conditions are prescribed as surface temperatures on the outside and inside boundaries and an adiabatic condition is imposed at the wall and floor periphery. The materials of each layer in this study are homogeneous and the property parameters are kept constant. The ambient temperatures were chosen to match the actual external air temperature $\left(T_{o}=-11.3^{\circ} \mathrm{C}\right)$ and the room heating temperature $\left(T_{i}=20^{\circ} \mathrm{C}\right)$ in the winter season of South Korea. The hot water temperature was $60^{\circ} \mathrm{C}$ that flowed into the hot water pipe in the heating layer of floor system. The velocity of hot water in pipe was set at $3 \mathrm{~L} / \mathrm{min}$. The set temperature for heating room was $20^{\circ} \mathrm{C}$. All environmental factors were controlled at the ideal thermal and physiological conditions.
TABLE 2: Calculation parameters.

\begin{tabular}{lc}
\hline Parameter & Assigned value \\
\hline Time step interval & 30 minutes \\
Maximum number of iterations & 10,000 \\
Maximum temperature difference & $0.0001^{\circ} \mathrm{C}$ \\
Heat flow divergence for total object & $0.001 \%$ \\
Heat flow divergence for worst node & $1 \%$ \\
Thermal conductivity of resilient & $0.029,0.031,0.037$, \\
material in floor & $0.046 \mathrm{~W} /(\mathrm{m} \cdot \mathrm{K})$ \\
\hline
\end{tabular}

\section{Results and Discussion}

3.1. Density and Thermal Conductivity of EPS Resilient Material. The measured apparent density of the EPS resilient materials ranged from 9.5 to $63.0 \mathrm{~kg} / \mathrm{m}^{3}$, and the thermal conductivity ranged from 0.030 to $0.046 \mathrm{~W} /(\mathrm{m} \cdot \mathrm{K})$. Figure 4 illustrates the correlation between the thermal conductivity and the apparent density. As shown in Figure 4, the measured thermal conductivity and the density show a linear correlation in

$$
\lambda_{\text {eps }}=-0.0093 \operatorname{Ln}\left(p_{x}\right)+0.0638,
$$

where $\lambda_{\text {eps }}$ is the thermal conductivity and $p_{x}$ is density of the EPS resilient materials. In this dotted line, the explosives exhibit $R^{2}$-correlation coefficient of 0.786 . The experiment results showed a close correlation between the apparent density and thermal conductivity. As the density of resilient materials made of EPS increases, the thermal conductivity tends to proportionately decrease. The resulting dotted line had a slope that decreased fast toward a high density.

On the basis of these results, it was found that the density is an important factor of the thermal property of resilient materials that are used in the floor systems of residential buildings. To prevent greater heat loss from a floor system 


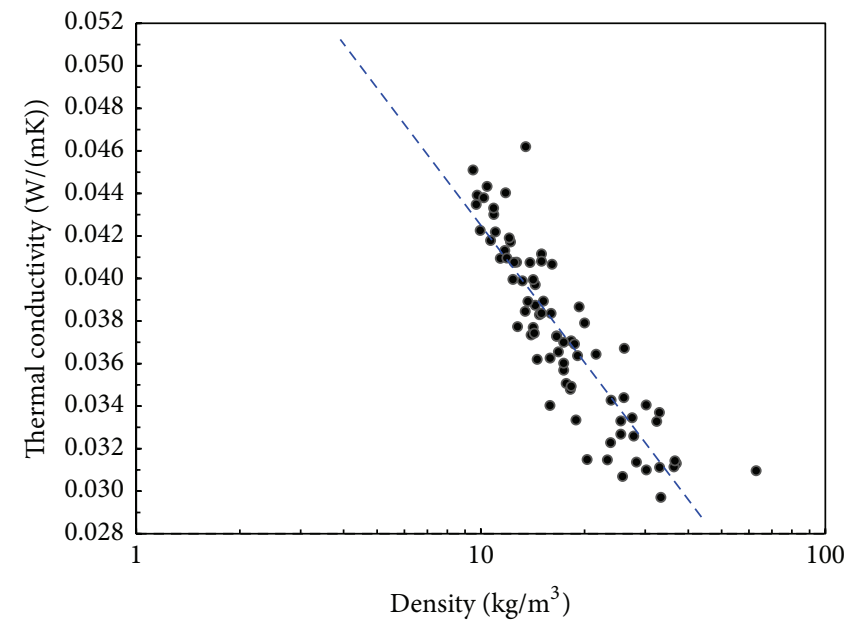

FIGURE 4: Correlation between the apparent density and thermal conductivity of the EPS resilient material.

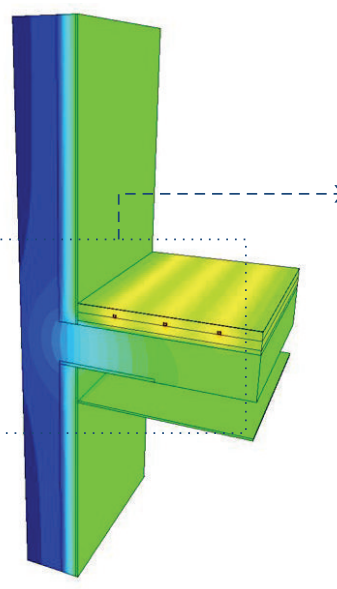

(a)

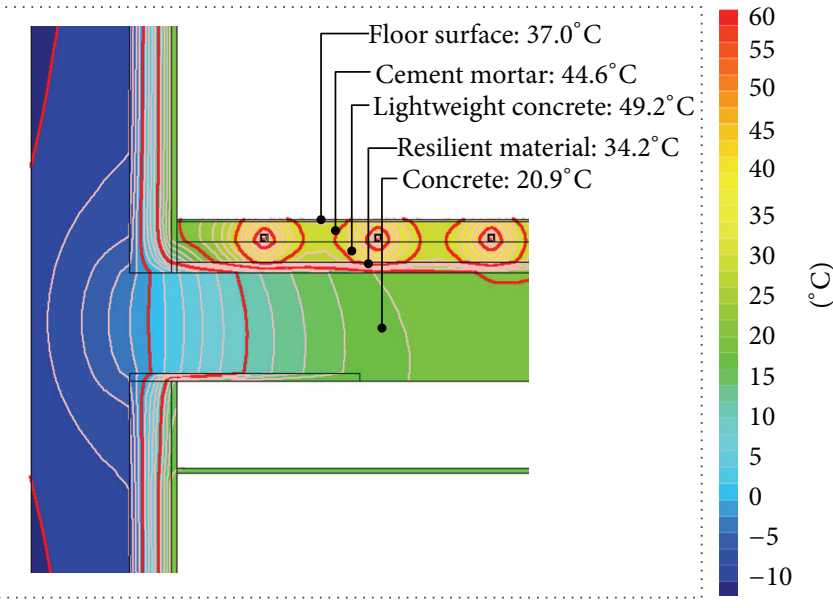

(b)

FIGURE 5: Thermal transfer properties of the radiant floor heating system at the time of the lowest external temperature in winter season. (a) Temperature distribution; (b) detailed thermal pattern. Thick red lines mean $5^{\circ} \mathrm{C}$ interval.

due to the different temperatures of a room and outdoors, the building insulation materials must be selected based on the correlation between the density and the thermal conductivity. But, at the same density, the thermal conductivity varied because of other factors affecting the thermal properties, that is, the physical structure of the cells of the materials varying depending on the manufacturing method, the size and type of internal air gaps, radiant heat flow rate, and so forth.

3.2. Thermal Transfer Characteristics. Numerical simulation was carried out to investigate the effect and thermal transfer characteristics of the radiant floor heating system based on the thermal conductivity of the resilient material. The simulation method used the steady-state condition of heat balance model based on the lowest external ambient temperature, and the thermal conductivity values of the EPS resilient material were the maximum, minimum, average, and median.
TABLE 3: Heat loss according to the thermal conductivity of EPS resilient material.

\begin{tabular}{lccc}
\hline & $\begin{array}{c}\text { Thermal conductivity } \\
(\mathrm{W} /(\mathrm{m} \cdot \mathrm{K}))\end{array}$ & $\begin{array}{c}\text { Heat loss } \\
(\mathrm{W})\end{array}$ & $\begin{array}{c}\text { Saving ratio } \\
(\%)\end{array}$ \\
\hline Case 1 & 0.029 & 46.83 & 3.4 \\
Case 2 & 0.031 & 47.07 & 2.9 \\
Case 3 & 0.037 & 47.70 & 1.6 \\
Case 4 & 0.046 & 48.46 & 0.0 \\
\hline
\end{tabular}

Table 3 and Figure 5 summarize the results of the numerical simulation. As shown in Table 3 , the amount of heat loss at each case was affected by the thermal property of the EPS resilient material. As the thermal conductivity of EPS resilient material increased 1.6 times, the heat loss of floor heating system was of $3.4 \%$ increase. Figure 5 shows the temperature distribution and heat flow pattern in the lowest external 
temperature. We see from Figure 5 that the heat loss occurred from heat water pipe in the radiant floor heating system that was meant to heat a space in the external structure. Heat loss occurred in the joint RC floor and the external wall. The cause of this heat loss is the thermal bridge of RC floor structure in an apartment building. Dependence on the thermal conductivity of EPS resilient material was lowered, and the insulation performance of the floor was increased. Because the flow of the heat flow ratio through wall-floor joint is lowered toward external wall, the heat loss decreased. It is clear that thermal conductivity of resilient material of $\mathrm{RC}$ floor structure with radiant floor heating systems in apartment housing of Korea can be an important factor.

In Korea, apartment housing must obey the building energy design code for energy saving and soundproofing. This code requires the $\mathrm{RC}$ floor structure with radiant floor heating system to have the thermal performance value less than or equal to $0.81 \mathrm{~W} /\left(\mathrm{m}^{2} \cdot \mathrm{K}\right)$. The thermal conductivity of EPS resilient material in the floor structure should be less than $0.031 \mathrm{~W} /(\mathrm{m} \cdot \mathrm{K})$ as case 2 in this study. When the thermal conductivity of EPS resilient material has more than $0.31 \mathrm{~W} /(\mathrm{m} \cdot \mathrm{K})$ as case 3 and case 4 , thickness of EPS resilient material also must have more than $20 \mathrm{~mm}$. Case $3(\lambda=$ $0.037 \mathrm{~W} /(\mathrm{m} \cdot \mathrm{K}))$ must be $24 \mathrm{~mm}$ thickness and case $4(\lambda=$ $0.037 \mathrm{~W} /(\mathrm{m} \cdot \mathrm{K}))$ must be more than $30 \mathrm{~mm}$ thickness to keep the design code.

\section{Conclusions}

We examine the changes in the thermal conductivity of representative resilient materials, expanded polystyrene foam according to the apparent density of them. From the results, we get the empirical formula that has the correlation between the thermal conductivity and the density. To set up reasonable thermal insulation requirements for the radiant heating floor systems of reinforced concrete floor, it is necessary to find out the thermal transfer property of floor systems according to the thermal insulation performance. So the heat transfer simulations were performed to analyze the surface temperature and heat loss of the floor structure with the radiant floor heating system.

Resilient materials are made of expanded polystyrene; as the density increased, the thermal conductivity tended to decrease. The experiment results showed the correlation expression between the thermal conductivity and the density, which allowed the determination of the adequate insulation materials and their thermal conductivity for a building energy code. When insulation materials are installed in the walls, floors, and roofs of a building to prevent heat loss and to reduce noise in buildings, materials must be used in consideration of not only the physical properties of the materials, but also their thermal properties [6]. The study showed that the conductivity of the resilient materials in reinforced concrete floor structure with radiant floor heating system affected the energy saving.

Thermal performance plays a significant role in the heat loss of building. The relative importance of thermal bridges increases in the energy balance of recent highly insulated buildings [19]. The simulation results showed that the temperatures of the external surface and the internal surface of the joint parts of the thermal bridge part and the normal part significantly differed in floor structure. Thus, the resilient materials on hot water pipe in a radiant floor heating system are an important point not only for reducing the floor impact sound level but also for preventing heat loss for space heating.

\section{Conflict of Interests}

The authors declare that there is no conflict of interests regarding the publication of this paper.

\section{References}

[1] K.-W. Kim, G.-C. Jeong, K.-S. Yang, and J.-Y. Sohn, "Correlation between dynamic stiffness of resilient materials and heavyweight impact sound reduction level," Building and Environment, vol. 44, no. 8, pp. 1589-1600, 2009.

[2] G.-S. Song, "Buttock responses to contact with finishing materials over the ONDOL floor heating system in Korea," Energy and Buildings, vol. 37, no. 1, pp. 65-75, 2005.

[3] S. Lee, J. Joo, and S. Kim, "Life cycle energy and cost analysis of thin flooring panels with enhanced thermal efficiency," Journal of Asian Architecture and Building Engineering, vol. 14, no. 1, pp. 167-173, 2015.

[4] Korea Ministry Construction \& Transportation (MOCT), Korea's Building Energy Code (MOCT Notification No 2010-1031), Korean Government, Seoul, Republic of Korea, 2010.

[5] Korea Institute of Construction Technology (KICT), Development of Thermal Insulation Design and Construction System of Building, KICT, Goyang-si, Republic of Korea, 1997.

[6] Y.-S. Jeong, H.-J. Choi, K.-W. Kim, G.-S. Choi, J.-S. Kang, and K.-S. Yang, "A study on the thermal conductivity of resilient materials," Thermochimica Acta, vol. 490, no. 1-2, pp. 47-50, 2009.

[7] Y. Liu, D. Wang, and J. Liu, "Study on heat transfer process for in-slab heating floor," Building and Environment, vol. 54, pp. 7785, 2012.

[8] X. Jin, X. Zhang, and Y. Luo, "A calculation method for the floor surface temperature in radiant floor system," Energy and Buildings, vol. 42, no. 10, pp. 1753-1758, 2010.

[9] A. B. Larbi, "Statistical modelling of heat transfer for thermal bridges of buildings," Energy and Buildings, vol. 37, no. 9, pp. 945-951, 2005.

[10] T. G. Theodosiou and A. M. Papadopoulos, "The impact of thermal bridges on the energy demand of buildings with double brick wall constructions," Energy and Buildings, vol. 40, no. 11, pp. 2083-2089, 2008.

[11] S.-Y. Song, B.-K. Koo, and B.-H. Choi, "Insulation performances of the typical floor's wall-slab and side wall-slab joints of apartment buildings with internal and external insulation systems," Journal of the Architectural Institute of Korea, vol. 24, pp. 277285, 2008.

[12] O. Kaynakli, "Parametric investigation of optimum thermal insulation thickness for external walls," Energies, vol. 4, no. 6, pp. 913-927, 2011.

[13] K. Goodier, "Making and using an expanded plastic," New Scientist, vol. 240, pp. 706-707, 1961. 
[14] Korea Standards Association (KSA), KS L 9016:2005 Method for Measuring Thermal Conductivity of Insulation, Korea Standards Association (KSA), Seoul, Republic of Korea, 2005.

[15] ISO, "Thermal insulation-determination of steady-state thermal resistance and related properties-heat flow meter apparatus," ISO 8301, International Organization for Standardization, 1991.

[16] Korea Ministry Construction \& Transportation (MOCT), "Korea's the authorization of isolation system and management code for floor impact sound in apartment houses," MOCT Notification 2009-1217, Korean Government, Seoul, Republic of Korea, 2009.

[17] Physibel, Physibel software, 2014, http://www.physibel.be/.

[18] ISO, "Thermal bridges in building construction-heat flows and surface temperatures-part 1: general calculation methods," ISO 10211-1, International Organization for Standardization, 1995.

[19] L. Zalewski, S. Lassue, D. Rousse, and K. Boukhalfa, "Experimental and numerical characterization of thermal bridges in prefabricated building walls," Energy Conversion and Management, vol. 51, no. 12, pp. 2869-2877, 2010. 

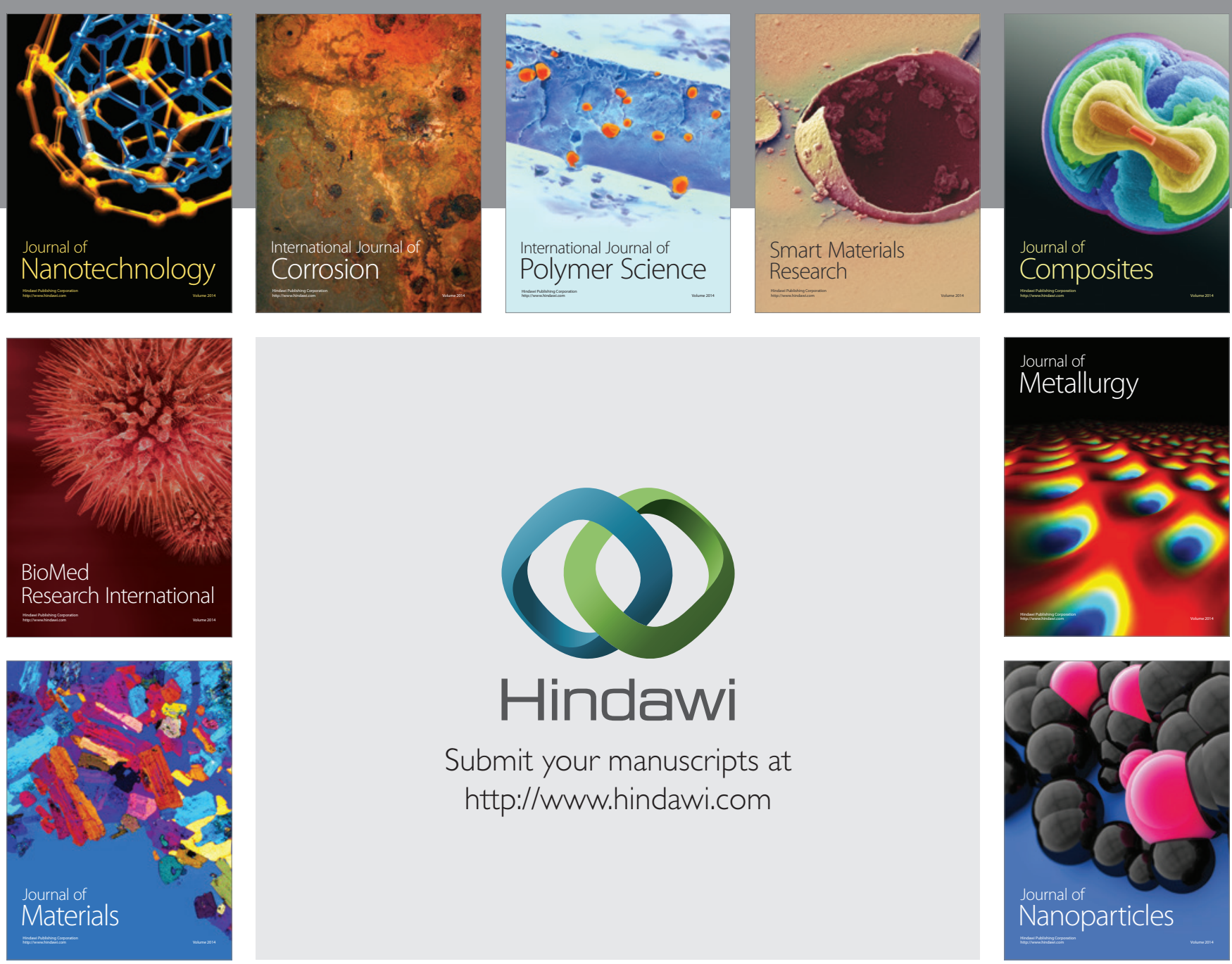

Submit your manuscripts at http://www.hindawi.com
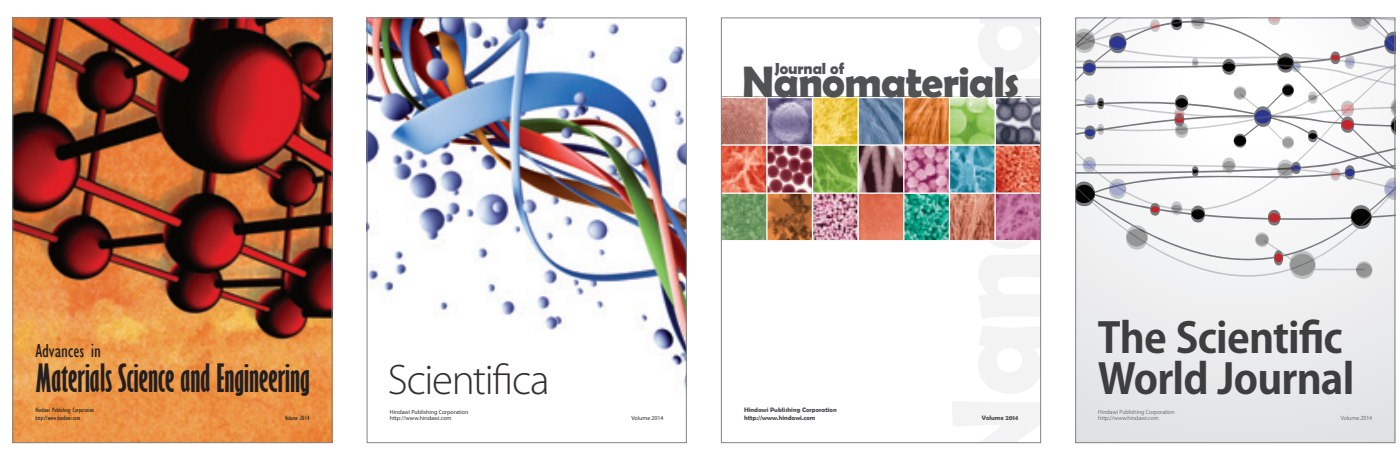

\section{The Scientific World Journal}
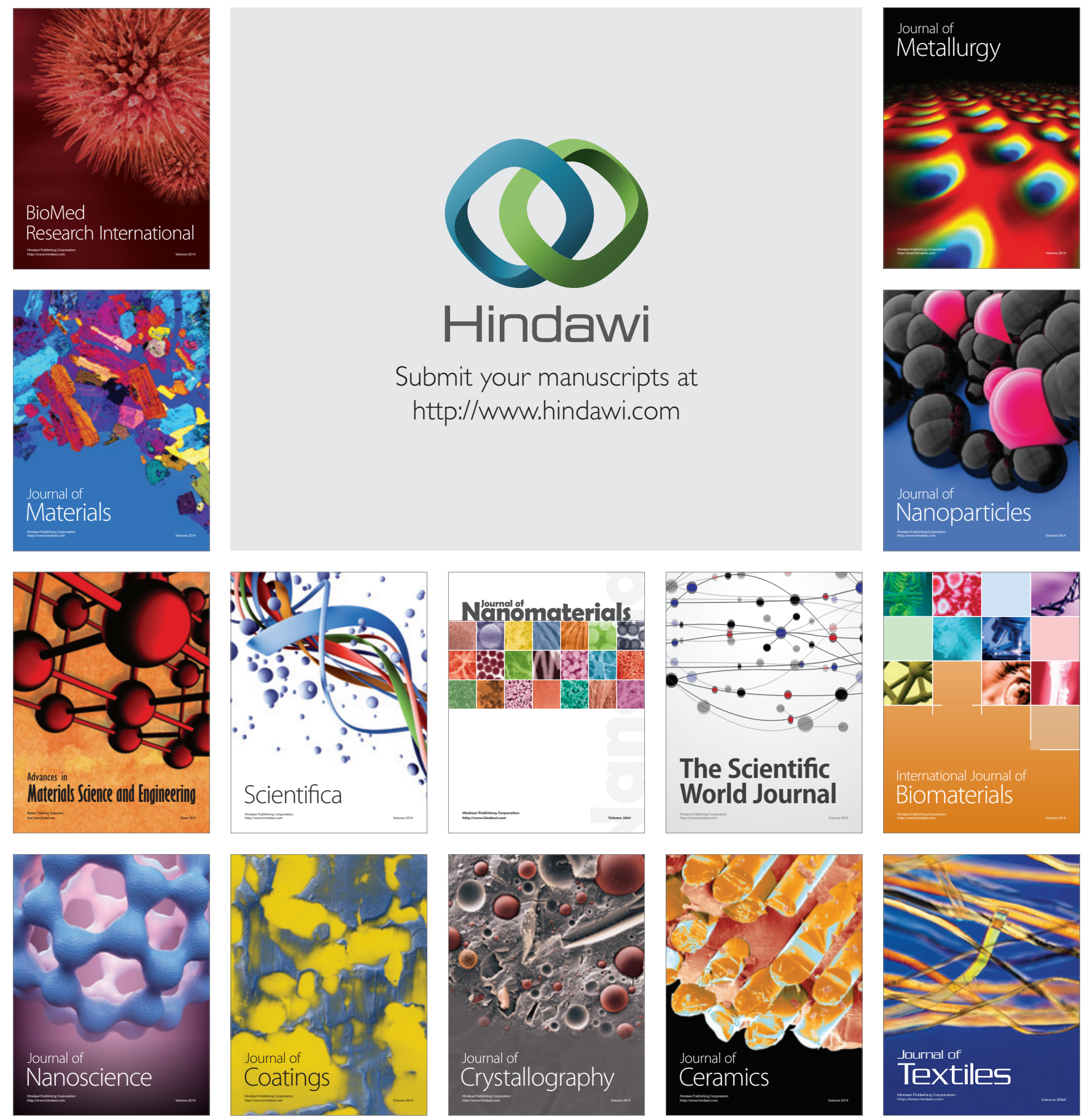